Çanakkale Onsekiz Mart University
Journal of Graduate School of Natural and Applied Sciences
Open Access

\title{
Observing the Water Quality in the Vicinity of Green Ports Located in the Marmara Sea, Turkey
}

\author{
Sevil Deniz Yakan Dündar ${ }^{1 *}$ \\ ${ }^{1}$ Department of Shipbuilding and Ocean Engineering, Faculty of Naval Architecture and Ocean Engineering, Istanbul Technical University, \\ Maslak, Istanbul, Turkey
}

$\begin{array}{ll}\text { Article History } \\ \text { Received: } & 17.12 .2019 \\ \text { Accepted: } & 04.03 .2020 \\ \text { Published: } & 00.05 .2020\end{array}$

Research Article

\begin{abstract}
Detection of biological, physical and chemical parameters is needed for the determination of water quality. Some of these water quality parameters such as turbidity, chlorophyll-a, harmful algae, suspended sediment, submerged habitat and temperature, can be derived directly via the satellite remote sensing facilities, particularly through the ocean color sensors. The competitiveness of satellite remote sensing comes from its capability of extensive geographical range and temporal coverage. Thus, changes and trends in water quality can be monitored and assessed to a greater degree, especially under the dynamic conditions of coastal zones. This study focuses on the water quality parameters in the vicinity of Green Ports of Turkey located in the Marmara Sea. There are 12 certified Green Ports in Turkey, located mostly in the Marmara Sea. Marmara Sea is a semi-enclosed inland sea and a passageway, which connects the Black Sea to the Mediterranean. There are 7 cities surrounding the Marmara Sea, representing the different anthropogenic aspects of civilization: Population, industry and agriculture. These aspects affect the water quality of the coastal zones in the Marmara Sea in different scales. Briefly, the aim of this study is to monitor and assess the impact of the Green Ports in the Marmara Sea region, in terms of water quality parameters detected via the Earth Observation System. Consequently, it is concluded that remote sensing capabilities of the contemporary Earth Observation Systems provide reliable results of water quality parameters when coupled with the field measurements in order to use in further decision-making mechanisms.
\end{abstract}

Keywords - Green port; remote sensing; ocean color; water quality; Turkey

\section{Introduction}

Since 1970's satellite remote sensing has been used in water quality monitoring and assessment studies. Remote sensing techniques are getting more popular as a global application of water quality due to the advances in its technology such as higher spectral and spatial resolutions in addition to the availability of its data in digital forms for further processing. By the help of the sensors mounted on satellites, electromagnetic radiation of the water surface reflections can be measured and utilized for the detection of various water quality parameters. Thus, spatial and temporal observations of surface waters and the quantification of the water quality parameters become possible by means of remote sensing (Alparslan, Aydöner, Tufekci, \& Tüfekci, 2007; Brando \& Dekker, 2003; Gholizadeh, Melesse, \& Reddi, 2016; Giardino et al., 2014; Hadjimitsis \& Clayton, 2009; Hellweger, Schlosser, Lall, \& Weissel, 2004; Koponen, Pulliainen, Kallio, \& Hallikainen, 2002; Morel \& Prieur, 1977; Ritchie, Zimba, \& Everitt, 2003; Seyhan \& Dekker, 1986; Usali \& Ismail, 2010). Several satellite sensors (e.g. Coastal Zone Color Scanner - CZCS, Sea-viewing Wide Fieldof-view Sensor - SeaWiFS, Medium Resolution Imaging Spectrometer - MERIS, Moderate resolution Imaging Spectroradiometer - MODIS) have been used to observe near real-time dynamics of aquatic environments (van der Woerd \& Wernand, 2015). However, CZCS, SeaWiFS and MERIS completed their missions in 1986, 2010 and 2012, respectively and MODIS is in charge for a long period of time, since 2002. In addition, none of these ocean color sensors was designed for the purpose of water quality monitoring. Thus, Ocean and Land Color Instrument (OLCI), a follow-up project and an imaging spectrometer for the

\footnotetext{
1 (D) https://orcid.org/0000-0003-2493-680X yakans@itu.edu.tr

*Corresponding Author
} 
monitoring of open, coastal and inland waters (Toming, Kutser, Tuvikene, Viik, \& Nõges, 2016; van der Woerd \& Wernand, 2015) was designed to be specialized in ocean color remote sensing (Wang, Ling, Yao, Liu, \& Xu, 2019). OLCI is attached on Sentinel-3A and Sentinel-3B satellites launched on the $16^{\text {th }}$ of February, 2016 and $25^{\text {th }}$ of April, 2018 respectively by European Space Agency (ESA). The swath width and the spatial resolution of OLCI is $1200 \mathrm{~km}$ and $300 \mathrm{~m}$, respectively and it has 21 spectral bands with a wide range, from optical to near-infrared wavelengths (Donlon et al., 2012; Petus et al., 2019; Wang et al., 2019). Since the design of the OLCI spectral bands was performed considering its specific aims, the images obtained via Sentinel-3 OLCI sensor are able to be used in mapping the parameters of the water quality (Toming et al., 2016; Wang et al., 2019).

There are many parameters of water quality, including hydrological, biological, physical and chemical aspects of the water itself and its constituents (Seyhan \& Dekker, 1986). Some of these constituents are able to be detected by means of remote sensing technology, depending on their photo-activeness and spectral characteristics, by interacting with light and changing the energy spectrum of the reflected electromagnetic radiation. The parameters of water quality detected via remote sensing are mostly focused on photo-active constituents of water, such as chlorophyll-a, colored dissolved organic matters, total organic carbon, dissolved organic carbon, total suspended matters and turbidity in addition to other remotely sensed parameters such as secchi disk depth, temperature, sea surface salinity, total phosphorus, ortho-phosphate, chemical oxygen demand, biochemical oxygen demand, electrical conductivity and ammonia nitrogen (Gholizadeh et al., 2016). The physical principles of light such as scattering, absorption and attenuation assist to detect and monitor the color change of the water bodies via ocean color sensors. In this study, three water quality parameters are selected to be focused on: Chlorophyll-a (Chl-a), Colored Dissolved Organic Matter (CDOM) and Total Suspended Matter (TSM). All of these parameters are photo-active and are accepted as important indicators of the water quality.

Chl-a is a well-known photosynthetic pigment of plants, plankton and cyanobacteria. At the same time, it is an essential element of photosynthesis process and it is used to estimate the biomass of phytoplankton in the water bodies. Due to its connecting role of nutrients with primary production, it is also evaluated as an important indicator of the trophic status of the water bodies. Because it reflects mainly green color and absorbs mostly violet-blue and orange-red color wavelengths, Chl-a is considered as an essential photo-active constituent of the water bodies (Gholizadeh et al., 2016; Schlichter, Kampmann, \& Conrady, 1997). Several spectral bands were evaluated for the determination of Chl-a in water bodies by means of different sensors (e.g. Landsat 5-TM, Landsat 5-MSS, Landsat 7-ETM+, SPOT, IRS-LISS-III, HICO, PROBA-CHRIS, MODIS, MERIS, AISA, EO-1 Hyperion, CASI, Daedalus Airborne Thematic Mapper). Chl-a absorbs light between blue $(450-475 \mathrm{~nm})$ and red $(670 \mathrm{~nm})$, but reflects at green $(550 \mathrm{~nm})$ and NIR (near infra-red, 700 $\mathrm{nm}$ ). Thus, several studies have been performed to develop Chl-a estimation algorithms by using the ratios of different spectral bands of these sensors, varying from blue to NIR (Gitelson et al., 2008; Han \& Jordan, 2005; Hoogenboom, Dekker, \& Althuis, 1998), in addition to remote sensing measurements of Chl-a (Alparslan, Coskun, \& Alganci, 2009; Colella, Falcini, Rinaldi, Sammartino, \& Santoleri, 2016; Ekercin, 2007; Oguz \& Gilbert, 2007). Therefore, Chl-a is accepted as one of the main indicators of water quality.

Another indicator of the water quality is the photo-active component of the dissolved organic matter, Colored Dissolved Organic Matter, CDOM, as it appears from its name. CDOM dissolves in water and is present in both fresh and salt water with a range of color from yellow to brown (Gholizadeh et al., 2016). The majority of the CDOM consists of humic and fulvic acids. Generally, CDOM is assigned as a measure of dissolved organic matter (Brezonik, Olmanson, Finlay, \& Bauer, 2015; Toming et al., 2016). However, the sources of CDOM can be both indigenous and exogenous. CDOM can originate from the water body itself due to the degradation of phytoplankton, and it can also originate from its catchment area (Blix, Pálffy, Tóth, \& Eltoft, 2018). Besides being an indicator of the water quality, CDOM is also an important parameter of carbon dynamics in aquatic ecology studies due to its biogenic and organic structure (Mannino, Russ, \& Hooker, 2008; Ritchie et al., 2003). It is observed that a correlation occurs between CDOM and dissolved organic carbon for both fresh and salt water ecosystems (Del Castillo, Gilbes, Coble, \& Müller-Karger, 2000; 
Del Castillo \& Miller, 2008; Ferrari, Hoepffner, \& Mingazzin, 1996; Spencer et al., 2007; Stedmon et al., 2006; Vignudelli, Santinelli, Murru, Nannicini, \& Seritti, 2004; Yu et al., 2010).

Together with Chl-a and CDOM, total suspended matter (TSM) dominate the color of the remotely sensed water bodies. TSM represents the particulate materials in the water bodies. They can be both organic and inorganic, and the origin of their location can be either in local or distant places, e.g. wind-induced resuspension or tributaries (Madsen, Chambers, James, Koch, \& Westlake, 2001). Water turbidity is an optical characteristic of the water and it is directly related with the suspended mater in the water (Wass, Marks, Finch, Leeks, \& Ingram, 1997). Absorption, scattering and transmission of light have different drivers in the aquatic environment, and while Chl-a and CDOM are responsible for the absorption, mostly scattering occurs in the regions of suspended sediment (Myint \& Walker, 2002). Mapping of spatial and temporal variations of the properties such as turbidity and suspended matter concentration is possible by means of remote sensing, and different spectral bands are utilized to represent the variations in the colors of the water bodies (Doxaran, Froidefond, Lavender, \& Castaing, 2002; Feng, Hu, Chen, \& Song, 2014; Nechad, Ruddick, \& Park, 2010).

It is an undeniable fact that the water quality has been adversely affected from the anthropogenic activities, urbanization and the industrial growth. Providing economic growth while reducing the adverse effects of port infrastructures paved the way for the development of sustainable port infrastructure and the concept of Green Port. The definition of Green Port explains well the context of this concept: "A product of the long-term strategy for the sustainable and climate-friendly development of the port's infrastructure" (Pavlic, Cepak, Sucic, Peckaj, \& Kandus, 2014). European Sea Ports Organization (ESPO) coordinated the EcoPorts project since 2011 to put the Green Port concept into operation in the European Union (EU) countries (EcoPorts, 2019). The establishment purpose of the EcoPorts network is to share the knowledge and experience in port environmental management. 25 countries are represented in the EcoPorts network and there are 113 members of EcoPorts. Only 2 Turkish ports are in the EcoPorts network: Asyaport Port Inc. with its certificate of Port Environmental Review System (PERS, certificate assessed by Lloyds register), and Marport Terminal Operators with its ISO 14001 certificate. Both of them are located in the Marmara Sea. There is another nonprofit foundation named as ECO SLC (Sustainable Logistics Chain), which focuses on the environmental protection of the ports outside Europe and port terminals worldwide (ECOSLC, 2019). There are 5 Turkish ports in the network of ECO SLC: Asyaport Port Inc. (PERS certified), Marport Terminal Operators (ISO certified), Altintel Port and Terminal Operators Inc. (ISO certified), Ege Port (Kusadasi Cruise Port) (both PERS and ISO certified), and Port Akdeniz (ISO certified). Three of these ports are located in the Marmara Sea, one is in the Aegean Sea, and the other one is in the Mediterranean. The Ministry of Transport, Communications and Maritime Affairs, General Directorate of Maritime Trade (DTGM) and Turkish Standards Institution (TSE) launched a collaboration project in December 2014 named as "Green Port / Eco Port" for the implementation of Green Port concept in Turkish waters. The requirements of having a Green Port certificate from the Ministry of Transport and Maritime Affairs and Communications are to have the certificates of TS EN ISO 9001 "Quality Management System", TS EN ISO 14001 "Environmental Management System" and OHSAS 180001 "Occupational Health and Safety Management System", in addition to meet the requirements of Sectoral Criteria Conformity (Akgul, 2017).

Currently, there are 12 ports in Turkey, which have Green Port certificate from the Ministry of Transport, Maritime Affairs and Communications: Marport in Beylikduzu, Istanbul; Borusan Logistics in Gemlik, Bursa; Evyap Port in Korfez, Kocaeli; Egeports in Kusadasi, Aydin; Aksaport in Yalova; Asyaport in Kumbag, Tekirdag; Petkim Port in Aliaga, Izmir; Bodrum Kruvaziyer Port in Bodrum, Mugla; Solventas Port in Dilovasi, Kocaeli; Ford Otosan Port in Golcuk, Kocaeli; Kumport in Beylikduzu, Istanbul and Mardas Port in Beylikduzu, Istanbul (Tanzer Satir, personal communication, 15 May 2019). Only 3 of them are located outside of the Marmara Sea, and the rest is located mostly in the east and north-west part of the Marmara Sea. Marmara Sea is a natural passageway between the Black Sea and the Mediterranean due to its geographical location. It composes Turkish Strait System (TSS) together with the Straits of Istanbul and Çanakkale. It is surrounded by the cities of the Marmara Region which has the highest population in the country. As a consequence, industrial and agricultural activities are intensive in this region, and Marmara Sea is directly affected from these anthropogenic activities. Therefore, it is important to have Green Port certified ports in this region 
of intense interest. Taking into consideration of the geographical location and geopolitical importance of the Marmara Sea together with the high industrial and agricultural activities due to its high population, it is a necessity to ensure the Green Port continuity in the Marmara Sea. Development and sustainability of Green Ports need extensive research, and monitoring studies of the water quality in the vicinity of Green Ports can also be regarded as worthwhile from the perspective of European Union (EU) Framework Directives, because it is known that each EU country has a must to report their status of water quality due to the Directives of Water Framework and the Marine Strategy (Carvalho et al., 2019). Hence, considering the benefits of remote sensing techniques on the coastal regions with limited data and funding, this study focuses on the selected water quality parameters (Chl-a, CDOM and TSM) in the vicinity of Green Ports located in the Marmara Sea.

\section{Materials and Methods}

\subsection{Study Area}

Marmara Sea is the connection of Black Sea to the Aegean and the Mediterranean Sea through the Straits of Istanbul and Çanakkale that form Turkish Strait System. Due to the different salinities and densities of the Black Sea and the Aegean Sea, Marmara Sea becomes a typical example of a stratified water body. The upper layer of the Marmara Sea represents the properties of the Black Sea, while the lower layer represents the characteristics of the Mediterranean. The mixing process and the circulation patterns of this two-layered water body have been analyzed in various studies in the perspective of physical and biogeochemical parameters (Beşiktepe et al., 1994; Yalçın, Artüz, Pavlidou, Çubuk, \& Dassenakis, 2017; Zeri et al., 2014).

Marmara Sea is selected as the focus area of the study, considering the capital intensiveness of the ports located in this region of interest. There are 68 member ports of the Ports Operators Association of Turkey (http://www.turklim.org/en/turklim-members/), and 39 of these ports are located in the region of the Marmara Sea. However, only 9 of these ports are Green Port certified as their locations are indicated in Figure 1 with green ellipses. The names, locations and graticules of these ports are listed in Table 1.

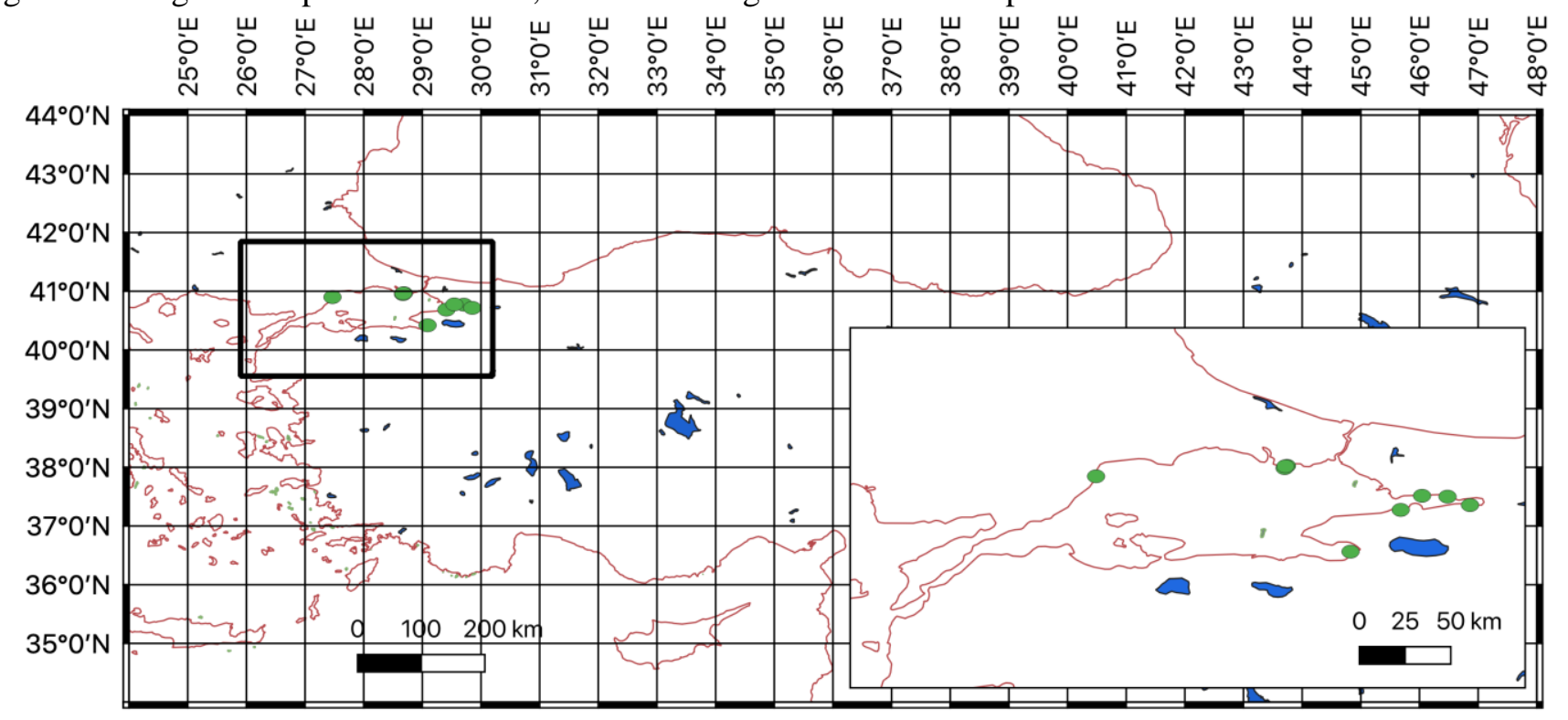

Figure 1. Locations of the 9 Green Ports in the Marmara Sea are indicated with green ellipses. The region of Marmara Sea is enlarged at the right bottom. Three of the ports (Marport, Kumport and Mardas Port) seem overlapped, because they are located closely in Beylikduzu, Istanbul, at the north of the Marmara Sea. This figure is produced by using QGIS Geographic Information System (https://qgis.org/en/site/). 
Table 1

The names and locations of Green Ports in the Marmara Sea, including their graticules.

\begin{tabular}{lllll}
\hline Port Name & County & City & Latitude & Longitude \\
\hline Marport & Beylikduzu & Istanbul & $40^{\circ} 57^{\prime} 51^{\prime \prime}$ & $28^{\circ} 40^{\prime} 31^{\prime \prime}$ \\
Borusan Logistics & Gemlik & Bursa & $40^{\circ} 24^{\prime} 54^{\prime \prime}$ & $29^{\circ} 04^{\prime} 49^{\prime \prime}$ \\
Evyap Port & Korfez & Kocaeli & $40^{\circ} 46^{\prime} 24^{\prime \prime}$ & $29^{\circ} 42^{\prime} 38^{\prime \prime}$ \\
Aksaport & Yalova & Yalova & $40^{\circ} 41^{\prime} 47^{\prime \prime}$ & $29^{\circ} 24^{\prime} 34^{\prime \prime}$ \\
Asyaport & Kumbag & Tekirdag & $40^{\circ} 54^{\prime} 02^{\prime \prime}$ & $27^{\circ} 28^{\prime} 15^{\prime \prime}$ \\
Solventas Port & Dilovasi & Kocaeli & $40^{\circ} 46^{\prime} 6^{\prime \prime}$ & $29^{\circ} 32^{\prime} 36^{\prime \prime}$ \\
Ford Otosan Port & Golcuk & Kocaeli & $40^{\circ} 43^{\prime} 51^{\prime \prime}$ & $29^{\circ} 51^{\prime} 21^{\prime \prime}$ \\
Kumport & Beylikduzu & Istanbul & $40^{\circ} 57^{\prime} 56^{\prime \prime}$ & $28^{\circ} 40^{\prime} 59^{\prime \prime}$ \\
Mardas Port & Beylikduzu & Istanbul & $40^{\circ} 57^{\prime} 46^{\prime \prime}$ & $28^{\circ} 40^{\prime} 11^{\prime \prime}$ \\
\hline
\end{tabular}

Although the surface area of the Marmara Sea is relatively small (approximately $11500 \mathrm{~km}^{2}$ ), it is divided into 22 Water Management Units depending on their different physical, biological and chemical properties (ÇŞB - ÇEDIDGM, 2018). Only 5 of these water management units cover the area of the Green Ports. The coverage area of these water management units and related Green Ports are shown in Table 2.

Table 2

Water Management Units (WMU) which covers the Green Ports in the Marmara Sea.

\begin{tabular}{lll}
\hline WMU & Coverage Area & Green Ports in the Area \\
\hline MAR - 08 & South of Tekirdag - Gelibolu Peninsula & Asyaport \\
MAR - 10 & $\begin{array}{l}\text { Between Buyukcekmece and Tekirdag } \\
\text { (in front of Kucukcekmece) }\end{array}$ & Marport, Kumport, Mardas Port \\
MAR - 16 & Izmit Inner Gulf & Ford Otosan Port \\
MAR - 17 & Izmit Outer Gulf & Evyaport, Solventas, Aksaport \\
MAR - 19 & Gemlik Gulf & Borusan Logistics \\
\hline
\end{tabular}

\subsection{Remotely Sensed Data}

The satellite data of the target area are downloaded from the open source of Copernicus Online Data Access (CODA - coda.eumetsat.int). The data is selected as Level-2 Full Resolution (spatial resolution of $300 \mathrm{~m}$ ) atmospherically corrected ocean color data. Downloaded data are visualized and evaluated using the freely accessible SNAP (Sentinel Applications Platform) software of the Science Toolbox Exploitation Platform of ESA (https://step.esa.int/main/toolboxes/snap/). Photo-active water quality parameters (Chl-a, CDOM and TSM) are detected via OLCI sensor on Sentinel 3A and 3B satellites and spatial maps are generated using its built-in algorithms specialized for the selected parameters. A Neural Network (NN) algorithm is used for the quantification of the monitored parameters (Brockmann et al., 2016; Doerffer \& Schiller, 2007). Locations of the selected Green Ports were pinned with their latitudes and longitudes, and the values of the pinned pixels were extracted for further evaluation. Level 2 water geophysical products of full resolution with the pixel size of $300 \times 300 \mathrm{~m}$ (OL_2_WFR) were used for the evaluation of the water quality products. In this product type, cloudy pixels are excluded, and only the pixels in water are taken into consideration in the final product. Spring and fall seasons were selected to be observed due to the relatively rapid changes of the water parameters in these seasons compared with the other seasons. This fact is also observed in the detections of Chl and CDOM absorption performed specifically in the Marmara Sea (Bengil \& Mavruk, 2018). Selected days were considered as two sets: Between $20^{\text {th }}$ of September and $20^{\text {th }}$ of November, 2018 (set 1) and between $20^{\text {th }}$ of March and $20^{\text {th }}$ of May 20, 2019 (set 2). Each day was scanned for the satellite data of the target area. However, regarding only the non-cloudy days over the target area, only 11 and 5 products were obtained for set 1 and 2 , respectively. 


\section{Results and Discussion}

The pixels belonging to the location of the 9 Green Ports were extracted separately using the tools of SNAP software and sorted out only for the selected water quality parameters: Chl-a (henceforth named as CHL), TSM and CDOM absorption. The results were summed up as set 1 and 2, indicating respectively the 2018 Fall and 2019 Spring seasons.

\subsection{Detected Water Quality Parameters for the 2018 Fall Season}

The detected values for the season of 2018 Fall (set 1) are given for the CDOM absorption, CHL and TSM, respectively in Tables 3-5. CDOM is also universally called as Gelb Stoff (yellow substance) due to its optical characteristics, and thus a specific wavelength, which is $443 \mathrm{~nm}$, is used for the determination of CDOM absorption in aquatic environments. OLCI sensor detects and determines the absorption of detritus and Gelb Stoff parameter at the wavelength of $443 \mathrm{~nm}$ named as ADG443 by using a neural network (NN) algorithm developed for the purpose of ocean color studies. The obtained values of ADG443 is given in Table 3, in terms of $\mathrm{m}^{-1}$ for each of the Green Ports, covering only the non-cloudy days of set 1 . Similarly, developed neural network algorithm was used for the determination of the CHL and TSM parameters in the vicinity of each Green Port for the non-cloudy days of set 1 , as shown in Table 4 in terms of $\mathrm{mg} \mathrm{m}^{-3}$ and in Table 5 in terms of $\mathrm{g} \mathrm{m}^{-3}$, respectively.

Table 3

Absorption of Detritus and Gelb Stoff parameter detected at $443 \mathrm{~nm}$ wavelength (ADG443), an indicator of CDOM parameter. NN: Neural network type of the algorithm. The first column lists the names of the ports, and the other head columns indicates the dates as year-month-day format. The unit of the absorption is $\mathrm{m}^{-1}$.

\begin{tabular}{lllll}
\hline ADG443_NN & 20180921 & 20180922 & 20181010 & 20181027 \\
\hline Asyaport & 0.08 & 0.07 & 0.03 & 1.23 \\
Marport & 2.66 & 3.49 & 2.79 & 0.52 \\
Mardas & 0.10 & 4.80 & 0.03 & 0.12 \\
Kumport & 0.13 & 0.29 & 0.12 & 0.07 \\
Ford Otosan & 0.38 & 0.52 & 1.29 & 3.83 \\
Evyapport & 0.12 & 0.18 & 0.18 & 0.40 \\
Solventas & 0.21 & 0.15 & 0.24 & 0.08 \\
Aksa Port & 0.19 & 2.79 & 0.06 & 0.35 \\
Borusan & 0.15 & 2.91 & 0.13 & 0.54 \\
\hline
\end{tabular}

Table 4

Chlorophyll-a parameter detected by using the neural network type of the algorithm (CHL_NN). The first column lists the names of the ports, and the others indicate the dates (year-month-day). The unit is $\mathrm{mg} \mathrm{m}^{-3}$.

\begin{tabular}{lllll}
\hline CHL_NN & 20180921 & 20180922 & 20181010 & 20181027 \\
\hline Asyaport & 0.40 & 0.75 & 0.19 & 7.09 \\
Marport & 8.49 & 12.66 & 11.35 & 0.83 \\
Mardas & 0.54 & 3.56 & 0.23 & 0.96 \\
Kumport & 0.80 & 2.22 & 0.67 & 0.42 \\
Ford Otosan & 3.43 & 1.16 & 5.70 & 5.30 \\
Evyapport & 0.28 & 0.43 & 0.48 & 1.55 \\
Solventas & 0.86 & 0.75 & 0.83 & 0.48 \\
Aksa Port & 0.36 & 15.17 & 0.27 & 1.16 \\
Borusan & 0.45 & 14.11 & 0.38 & 1.72 \\
\hline
\end{tabular}


Table 5

Total suspended matter parameter detected by using the neural network type of the algorithm (TSM_NN). The first column lists the names of the ports, and the other head columns indicates the dates as year-monthday format. The unit of TSM is $\mathrm{g} \mathrm{m}^{-3}$.

\begin{tabular}{lllll}
\hline TSM_NN & 20180921 & 20180922 & 20181010 & 20181027 \\
\hline Asyaport & 0.26 & 2.30 & 0.54 & 5.91 \\
Marport & 8.81 & 2.48 & 2.39 & 5.91 \\
Mardas & 1.39 & 13.13 & 0.42 & 2.66 \\
Kumport & 1.72 & 1.55 & 0.39 & 1.72 \\
Ford Otosan & 5.70 & 5.50 & 1.99 & 3.08 \\
Evyapport & 1.39 & 2.39 & 0.34 & 0.47 \\
Solventas & 2.97 & 2.76 & 0.42 & 0.80 \\
Aksa Port & 2.14 & 2.14 & 0.80 & 1.11 \\
Borusan & 0.47 & 1.99 & 0.50 & 3.97 \\
\hline
\end{tabular}

\subsection{Detected Water Quality Parameters for the 2019 Spring Season}

The extracted and summed up data of the pixels in the vicinity of the Green Ports for the spring season of 2019 are shown in Tables 6-8 for CDOM absorption (ADG443), CHL and TSM, respectively. The number of the selected days are higher compared with the fall season, because of the higher number of non-cloudy days detected by the ocean color sensors attached on the satellites. Because only the Level 2 geophysical water products are interested in this study, cloudiness of the detected day and time is important for the evaluation of the data. As a principle, non-cloudy pixels are selected for the Level 2 Water Full Resolution products of OLCI ocean color sensor (OL_L2_WFR). Additionally, there are two different detections for the same day of 25 March 2019 and 5 April 2019, because these days are detected by both of the Sentinel 3A and $3 \mathrm{~B}$ satellites. The inequality of the data extracted from two satellites draws attention to the importance of the field measurements of the water quality parameters.

Table 6

Absorption of Detritus and Gelb Stoff parameter detected at $443 \mathrm{~nm}$ wavelength (ADG443), which can be used as an indicator of CDOM parameter. $\mathrm{NN}$ extension in the name of the detected parameter shows the neural network type of the algorithm. The first column lists the names of the ports, and the other head columns indicates the dates as year-month-day format. The unit of the absorption is $\mathrm{m}^{-1}$.

\begin{tabular}{llllllllllll}
\hline ADG443_NN & 2019 & 2019 & 2019 & 2019 & 2019 & 2019 & 2019 & 2019 & 2019 & 2019 & 2019 \\
& 0322 & $\begin{array}{l}0325- \\
\text { S3B }\end{array}$ & 0325 & 0326 & 0329 & $0405-$ & 0417 & 0421 & 0422 & 0430 & 0519 \\
& & & & & S3B & & & & & \\
\hline Asyaport & 4.00 & 0.32 & 1.29 & 4.38 & 3.83 & 3.66 & 1.85 & 3.49 & 4.00 & 4.38 & 1.41 \\
Marport & 3.83 & 4.19 & 3.83 & 3.83 & 2.66 & 3.19 & 0.21 & 2.03 & 3.83 & 3.83 & 2.66 \\
Mardas & 3.83 & 0.72 & 3.34 & 3.83 & 1.23 & 3.66 & 0.06 & 0.09 & 2.12 & 2.66 & 0.29 \\
Kumport & 0.94 & 3.83 & 0.62 & 0.30 & 0.30 & 0.10 & 0.04 & 0.12 & 0.11 & 0.50 & 3.83 \\
Ford Otosan & 0.14 & 0.11 & 0.21 & 0.25 & 0.62 & 0.16 & 0.02 & 0.09 & 0.48 & 1.55 & 0.45 \\
Evyapport & 2.66 & 0.60 & 4.19 & 5.25 & 0.02 & 0.20 & 0.57 & 0.02 & 4.80 & 4.19 & 0.28 \\
Solventas & 2.91 & 0.17 & 0.75 & 3.83 & 0.52 & 0.18 & 0.03 & 1.55 & 0.28 & 0.20 & 0.21 \\
Aksa Port & 0.23 & 0.23 & 0.29 & 3.83 & 0.15 & 0.09 & 0.03 & 0.35 & 0.54 & 1.85 & 0.43 \\
Borusan & 0.10 & 0.13 & 0.30 & 0.36 & 0.32 & 0.12 & 0.02 & 0.07 & 0.52 & 0.65 & 0.35 \\
\hline
\end{tabular}


Table 7

Chlorophyll-a parameter detected by using the neural network type of the algorithm (CHL_NN). The first column lists the names of the ports, and the other head columns indicates the dates as year-month-day format. The unit of CHL is $\mathrm{mg} \mathrm{m}^{-3}$.

\begin{tabular}{llllllllllll}
\hline CHL_NN & 2019 & $\begin{array}{l}2019 \\
0325-\end{array}$ & 2019 & 2019 & 2019 & 2019 & 2019 & 2019 & 2019 & 2019 & 2019 \\
& 0322 & 0326 & 0329 & $0405-$ & 0417 & 0421 & 0422 & 0430 & 0519 \\
& & S3B & & & & S3B & & & & & \\
\hline Asyaport & 12.21 & 2.76 & 9.82 & 6.36 & 6.36 & 12.21 & 9.82 & 7.62 & 4.59 & 3.83 & 7.09 \\
Marport & 12.21 & 3.69 & 7.35 & 12.66 & 7.62 & 10.95 & 0.80 & 10.56 & 8.81 & 11.77 & 11.35 \\
Mardas & 5.70 & 5.30 & 7.09 & 10.56 & 6.36 & 11.77 & 0.45 & 0.60 & 13.61 & 11.77 & 0.96 \\
Kumport & 2.97 & 11.77 & 3.69 & 2.39 & 0.83 & 0.65 & 0.34 & 0.35 & 0.48 & 2.57 & 10.95 \\
Ford Otosan & 1.49 & 0.56 & 1.08 & 1.44 & 4.27 & 1.04 & 0.26 & 0.32 & 1.11 & 7.90 & 0.78 \\
Evyapport & 10.18 & 2.22 & 4.76 & 0.36 & 0.08 & 1.11 & 2.14 & 0.14 & 1.85 & 4.59 & 1.04 \\
Solventas & 14.63 & 1.08 & 3.83 & 5.70 & 1.72 & 0.96 & 0.26 & 9.47 & 2.30 & 0.65 & 2.22 \\
Aksa Port & 0.34 & 1.79 & 0.20 & 11.77 & 0.17 & 0.38 & 0.30 & 0.38 & 0.60 & 11.77 & 0.48 \\
Borusan & 0.52 & 0.65 & 0.72 & 1.39 & 0.52 & 0.65 & 0.13 & 0.45 & 4.11 & 3.69 & 1.20 \\
\hline
\end{tabular}

Table 8

Total suspended matter parameter detected by using the neural network type of the algorithm (TSM_NN). The first column lists the names of the ports, and the other head columns indicates the dates as year-monthday format. The unit of TSM is $\mathrm{g} \mathrm{m}^{-3}$.

\begin{tabular}{|c|c|c|c|c|c|c|c|c|c|c|c|}
\hline TSM_NN & $\begin{array}{l}2019 \\
0322\end{array}$ & $\begin{array}{l}2019 \\
0325- \\
\text { S3B }\end{array}$ & $\begin{array}{l}2019 \\
0325\end{array}$ & $\begin{array}{l}2019 \\
0326\end{array}$ & $\begin{array}{l}2019 \\
0329\end{array}$ & $\begin{array}{l}2019 \\
0405- \\
\text { S3B }\end{array}$ & $\begin{array}{l}2019 \\
0417\end{array}$ & $\begin{array}{l}2019 \\
0421\end{array}$ & $\begin{array}{l}2019 \\
0422\end{array}$ & $\begin{array}{l}2019 \\
0430\end{array}$ & $\begin{array}{l}2019 \\
0519\end{array}$ \\
\hline Asyaport & 69.59 & 1.99 & 2.76 & 26.14 & 17.54 & 60.19 & 2.57 & 20.28 & 5.91 & 8.81 & 1.55 \\
\hline Marport & 62.41 & 6.59 & 3.08 & 69.59 & 8.19 & 31.34 & 0.50 & 1.66 & 25.21 & 50.21 & 6.83 \\
\hline Mardas & 9.47 & 0.90 & 4.93 & 43.43 & 1.55 & 46.70 & 0.40 & 0.47 & 1.55 & 1.85 & 0.62 \\
\hline Kumport & 2.66 & 53.99 & 0.93 & 0.96 & 0.48 & 1.92 & 0.29 & 0.65 & 1.72 & 1.20 & 41.88 \\
\hline Ford Otosan & 4.11 & 1.20 & 1.08 & 2.48 & 3.83 & 0.67 & 0.29 & 0.28 & 1.72 & 1.66 & 3.83 \\
\hline Evyapport & 5.50 & 0.54 & 36.23 & 45.03 & 0.08 & 0.80 & 0.75 & 0.11 & 6.13 & 4.76 & 0.39 \\
\hline Solventas & 1.92 & 1.60 & 0.80 & 4.59 & 0.54 & 2.76 & 0.20 & 2.57 & 1.92 & 1.16 & 7.62 \\
\hline Aksa Port & 1.79 & 1.55 & 1.99 & 55.98 & 1.04 & 1.29 & 0.32 & 2.48 & 4.59 & 1.60 & 4.93 \\
\hline Borusan & 1.11 & 1.20 & 1.00 & 0.67 & 1.34 & 2.22 & 0.13 & 0.30 & 2.86 & 1.92 & 1.24 \\
\hline
\end{tabular}

As indicated, it is important to validate the sensor detected data with the field measurements. They have to be compatible with each other, and match-up. That is a necessary part of the ocean color studies. However, this match-up is out of the scope of the present study. It requires a comprehensive field and laboratory work with the necessary equipment such as spectrometer to detect the reflectance, radiance and irradiance of light, in addition to the spectrophotometers and filters of 0.7 and 0.2 um pore sizes together with the amber-colored water bottles to filter and measure the water properties collected from the vicinity of the selected ports. Therefore, this study focuses on only the data of ocean color sensors attached on the satellites. Consequently, the average values of the results shown in Tables 3-8 are calculated and presented in Table 9.

\subsection{Average Values and Comparisons}

The ranges of ADG443, CHL and TSM in set 1 vary between $0.03-4.80 \mathrm{~m}^{-1}, 0.19-15.17 \mathrm{mg} \mathrm{m}^{-3}$ and $0.26-$ $13.13 \mathrm{~g} \mathrm{~m}^{-3}$, respectively. Although there is only 1-day interval for the first two detections of set 1 , the differences of the CHL values in the vicinity of Aksa Port and Borusan seems as if they are out of ordinary. Similarly, for the second non-cloudy day of set 1 (third columns of Tables 3-5), maximum values of 
ADG443 and TSM were obtained in the vicinity of Mardas port. Moreover, the detected values were higher in the vicinity of Aksa Port and Borusan for ADG443 parameter and in the vicinity of Asyaport for TSM parameter. However, they are not excluded from the data set used to calculate the average values of the selected water quality parameters as shown in Table 9.

The ranges of ADG443, CHL and TSM in set 2 vary between $0.02-4.80 \mathrm{~m}^{-1}, 0.13-14.63 \mathrm{mg} \mathrm{m}^{-3}$ and 0.08 $69.59 \mathrm{~g} \mathrm{~m}^{-3}$, respectively. The ranges of set 2 are similar to the ranges of set 1 for the detections of ADG443 and CHL parameters. On the other hand, the values of TSM in set 2 are widely ranged with a maximum value of $69.59 \mathrm{~g} \mathrm{~m}^{-3}$. One reason for this wide variation could be the seasonal effects. Therefore, all of the detected values are included for the calculations of average values shown in Table 9.

Table 9

Average values of the selected water quality parameter in the vicinity of 9 Green Ports located in the Marmara Sea for the seasons of Fall 2018 (set 1) and Spring 2019 (set 2).

\begin{tabular}{lcccccc}
\hline & ADG443 $\left(\mathrm{m}^{-1}\right)$ & \multicolumn{2}{c}{ CHL $\left(\mathrm{mg} \mathrm{m}^{-3}\right)$} & \multicolumn{2}{c}{ TSM $\left(\mathrm{g} \mathrm{m}^{-3}\right)$} & \\
& 2018 Fall & 2019 Spring & 2018 Fall & 2019 Spring & 2018 Fall & 2019 Spring \\
\hline Asyaport & 0.35 & 2.96 & 2.11 & 7.51 & 2.25 & 19.76 \\
Marport & 2.37 & 3.10 & 8.33 & 8.89 & 4.90 & 24.15 \\
Mardas & 1.26 & 1.98 & 1.32 & 6.74 & 4.40 & 10.17 \\
Kumport & 0.15 & 0.97 & 1.03 & 3.36 & 1.35 & 9.70 \\
Ford Otosan & 1.50 & 0.37 & 3.90 & 1.84 & 4.07 & 1.92 \\
Evyapport & 0.22 & 2.07 & 0.69 & 2.59 & 1.14 & 9.12 \\
Solventas & 0.17 & 0.97 & 0.73 & 3.89 & 1.74 & 2.33 \\
Aksa Port & 0.85 & 0.73 & 4.24 & 2.56 & 1.55 & 7.05 \\
Borusan & 0.94 & 0.27 & 4.17 & 1.28 & 1.73 & 1.27 \\
\hline
\end{tabular}

The average values of a widespread, global data set is formed by merging field measurement data from different sources: NASA NOMAD and COLORS. NOMAD is the acronym of the NASA bio-Optical Marine Algorithm Dataset. It is freely accessible via https://seabass.gsfc.nasa.gov/wiki/NOMAD, but available only for educational and scientific research. This data set contains more than 3400 stations of both apparent (e.g. water-leaving radiances, surface irradiances, diffuse downwelling attenuation coefficients) and inherent (e.g. phytoplankton pigments) optical parameters of water (Werdell \& Bailey, 2005). COLORS is the abbreviation of the project named "Coastal region long-term measurements for colour remote sensing development and validation", funded by European Commission between the years of 1997 and 2000. Information related to the COLORS project can be accessed via the websites of Coastal Union Germany (EUCC-D) (http://databases.eucc-d.de/plugins/projectsdb/project.php?show=234) and NASA Global Change Master Directory (https://gcmd.gsfc.nasa.gov). Optical parameters of both data sets had been combined and represented as a global reference data set for the comparison of Baltic Sea to the other aquatic environments (Kratzer \& Moore, 2018). Inherent optical parameters of water (Chl-a, TSM and CDOM), which are also important indicators of water quality studies were collocated by Kratzer \& Moore (2018) from this combined data set. They grouped the values of $1982 \mathrm{Chl}-\mathrm{a}, 556 \mathrm{TSM}$ and $860 \mathrm{CDOM}$ absorption measurements with a range of $0.02-70.2 \mathrm{ug} \mathrm{L}^{-1}, 0.01-81.2 \mathrm{~g} \mathrm{~m}^{-3}$, and $0.001-0.6 \mathrm{~m}^{-1}$, respectively.

Another dataset used for the comparison is from the database of the GlobColour project funded by ESA (http://globcolour.info). It is freely available only for research and educational uses, not for commercial uses, and the data has been developed, validated and distributed by ACRI-ST, France (http://hermes.acri.fr/index.php?class=acknowledgement). Bengil \& Mavruk (2018) evaluated 10 years of time period between September 1997 and March 2007 by focusing on the Marmara Sea and generating 235 composite imaging products from the GlobColour dataset. They divided Marmara Sea into two sub-regions as western and eastern due to their different oceanographic characteristics and dynamics (Beşiktepe et al., 
1994), and calculated the monthly mean averages of 10 years of time period as 1.62 and $1.93 \mathrm{mg} \mathrm{m}^{-3}$ with a range of 0.42-6.53 and 0.42-7.01 for chlorophyll, and 0.14 and $0.16 \mathrm{~m}^{-1}$ with a range of 0.06-0.45 and 0.080.36 for CDOM absorption for the western and eastern Marmara Sea, respectively (Bengil \& Mavruk, 2018).

When the average values of the data set of this study, as shown in Table 9, is compared with the mentioned data sets above, it is seen that detected CDOM absorption (ADG443) values are higher than the measurements of the global reference data set and the database of the GlobColour project, especially in the vicinity of Marport and Mardas. The average values of CHL parameter of this study vary between $0.69-8.89 \mathrm{mg} \mathrm{m}^{-3}$, and the results are reasonable compared with the other data sets which range between $0.42-7.01 \mathrm{mg} \mathrm{m}^{-3}$ for the Marmara Sea. Similarly, average values of TSM parameter in the vicinity of Green Ports are within the range of the global reference data set, with a minimum and maximum value of 1.14 and $24.15 \mathrm{~g} \mathrm{~m}^{-3}$, respectively. As an overall evaluation of the present study, it is easily said that the remote sensing capabilities of the OLCI sensor attached on Sentinel-3 satellites enable reasonable detections for the observation of the water quality parameters. However, it is important to emphasize that remote sensing studies should be coupled with field measurements for reliable results. This fact comes into prominence in the regions of dominant anthropogenic activities such as ports, especially in the vicinity of Green Port certified ports, considering the purpose of the certification as sustainable and climate-friendly port development.

\section{Conclusion}

It is apparent that to obtain data via satellites provides a huge advantage for the observations of the water quality parameters in the vicinity of certified Green Ports in Marmara Sea, on behalf of being open access data on a wide range of geographical area with a high resolution of $300 \mathrm{~m}$ to $300 \mathrm{~m}$ for inland, coastal and open water zones, supported with its neural network algorithms. However, it should be taken into consideration that the validation of the data is a must, in order to do for a final evaluation and decisionmaking, regarding these two steps as complements of each other. Apart from the match-up of the field and the detected data, the values should be compared with the local and global water quality limits, if any of them exists for the selected locations. These steps should be seen as the regular studies that need to be done for the development and sustainability of Green Ports from the perspective of environmental studies.

\section{Acknowledgement}

The author would like to thank Assoc. Prof. Dr. Tanzer Satır from Istanbul Technical University, Faculty of Maritime for providing the names of the certified Green Ports in Turkey. She also would like to thank Assist. Prof. Dr. Bilge Tutak from Istanbul Technical University, Faculty of Naval Architecture and Ocean Engineering for guiding the author to use the software of Geographical Information System, QGIS, a product of the Open Source Geospatial Foundation Project. Moreover, the author thanks European Space Agency for free Sentinel-3 images, and she appreciates the anonymous reviewers for their comments and suggestions on the improvement of the manuscript.

\section{Author Contributions}

Sevil Deniz YAKAN DÜNDAR: Conceived and designed the paper, collected data, performed the analysis, and wrote the paper.

\section{Conflicts of Interest}

The authors declare no conflict of interest.

\section{References}

Akgul, B. (2017). Green Port / Eco Port Project-Applications and Procedures in Turkey. IOP Conference Series: Earth and Environmental Science, 95(4). https://doi.org/10.1088/1755-1315/95/4/042063

Alparslan, E., Aydöner, C., Tufekci, V., \& Tüfekci, H. (2007). Water quality assessment at Ömerli Dam using remote sensing techniques. Environmental Monitoring and Assessment, 135(1-3), 391-398. https://doi.org/10.1007/s10661-007-9658-6

Alparslan, E., Coskun, H. G., \& Alganci, U. (2009). Water quality determination of Küçükçekmece Lake, 
Turkey by using multispectral satellite data. TheScientificWorldJournal, 9, 1215-1229. https://doi.org/10.1100/tsw.2009.135

Bengil, F., \& Mavruk, S. (2018). Bio-optical trends of seas around Turkey: An assessment of the spatial and temporal variability. Oceanologia, 60(4), 488-499. https://doi.org/10.1016/j.oceano.2018.03.004

Beşiktepe, Ş. T., Sur, H. I. do., Özsoy, E., Latif, M. A., Oğuz, T., \& Ünlüata, Ü. (1994). The circulation and hydrography of the Marmara Sea. Progress in Oceanography, 34(4), 285-334. https://doi.org/10.1016/0079-6611(94)90018-3

Blix, K., Pálffy, K., Tóth, V. R., \& Eltoft, T. (2018). Remote sensing of water quality parameters over Lake Balaton by using Sentinel-3 OLCI. Water (Switzerland), 10(10). https://doi.org/10.3390/w10101428

Brando, V. E., \& Dekker, A. G. (2003). Satellite hyperspectral remote sensing for estimating estuarine and coastal water quality. IEEE Transactions on Geoscience and Remote Sensing, 41(6 PART I), 13781387. https://doi.org/10.1109/TGRS.2003.812907

Brezonik, P. L., Olmanson, L. G., Finlay, J. C., \& Bauer, M. E. (2015). Factors affecting the measurement of CDOM by remote sensing of optically complex inland waters. Remote Sensing of Environment, 157, 199-215. https://doi.org/10.1016/j.rse.2014.04.033

Brockmann, C., Roland, Peters, M., Kerstin, Sabine, \& Ruescas, A. (2016). Evolution of the C2RCC Neural Network for Sentinel 2 and 3 for the Retrieval of Ocean Colour Products in Normal and Extreme Optically Complex Waters.

Carvalho, L., Mackay, E. B., Cardoso, A. C., Baattrup-Pedersen, A., Birk, S., Blackstock, K. L., ... Solheim, A. L. (2019). Protecting and restoring Europe's waters: An analysis of the future development needs of the Water Framework Directive. Science of the Total Environment, 658, 1228-1238. https://doi.org/10.1016/j.scitotenv.2018.12.255

Colella, S., Falcini, F., Rinaldi, E., Sammartino, M., \& Santoleri, R. (2016). Mediterranean ocean colour chlorophyll trends. PLoS ONE, 11(6), 1-16. https://doi.org/10.1371/journal.pone.0155756

ÇŞB - ÇEDIDGM. (2018). Marine Quality Bulletin - Marmara Sea. Retrieved from https://webdosya.csb.gov.tr/db/ced/icerikler/mar-ne-qual-ty-bullet-n-2018_marmara-sea20180319074908.pdf

Del Castillo, C. E., Gilbes, F., Coble, P. G., \& Müller-Karger, F. E. (2000). On the dispersal of riverine colored dissolved organic matter over the West Florida Shelf. Limnology and Oceanography, 45(6), 1425-1432. https://doi.org/10.4319/lo.2000.45.6.1425

Del Castillo, C. E., \& Miller, R. L. (2008). On the use of ocean color remote sensing to measure the transport of dissolved organic carbon by the Mississippi River Plume. Remote Sensing of Environment, 112(3), 836-844. https://doi.org/10.1016/j.rse.2007.06.015

Doerffer, R., \& Schiller, H. (2007). The MERIS case 2 water algorithm. International Journal of Remote Sensing, 28(3-4), 517-535. https://doi.org/10.1080/01431160600821127

Donlon, C., Berruti, B., Buongiorno, A., Ferreira, M. H., Féménias, P., Frerick, J., ... Sciarra, R. (2012). The Global Monitoring for Environment and Security (GMES) Sentinel-3 mission. Remote Sensing of Environment, 120(2012), 37-57. https://doi.org/10.1016/j.rse.2011.07.024

Doxaran, D., Froidefond, J.-M., Lavender, S., \& Castaing, P. (2002). Spectral signature of highly turbid waters. Remote Sensing of Environment, 81(1), 149-161. https://doi.org/10.1016/s00344257(01)00341-8

Ekercin, S. (2007). Water quality retrievals from high resolution ikonos multispectral imagery: A case study in Istanbul, Turkey. Water, Air, and Soil Pollution, 183(1-4), 239-251. https://doi.org/10.1007/s11270-007-9373-5

Feng, L., Hu, C., Chen, X., \& Song, Q. (2014). Influence of the Three Gorges Dam on total suspended matters in the Yangtze Estuary and its adjacent coastal waters: Observations from MODIS. Remote Sensing of Environment, 140, 779-788. https://doi.org/10.1016/j.rse.2013.10.002

Ferrari, G. M., Hoepffner, N., \& Mingazzin, M. (1996). Optical properties of the water in a Deltaic environment: Prospectivetool to analyze satellite data in turbid waters. Remote Sensing of Environment, 58(1), 69-80. https://doi.org/10.1016/0034-4257(96)00058-2

Gholizadeh, M., Melesse, A., \& Reddi, L. (2016). A Comprehensive Review on Water Quality Parameters $\begin{array}{llllll}\text { Estimation Using Remote Sensing Techniques. Sensors, } 16(8), & 1298 .\end{array}$ https://doi.org/10.3390/s16081298

Giardino, C., Bresciani, M., Cazzaniga, I., Schenk, K., Rieger, P., Braga, F., Brando, V. E. (2014). Evaluation of multi-resolution satellite sensors for assessing water quality and bottom depth of Lake 
Garda. Sensors (Switzerland), 14(12), 24116-24131. https://doi.org/10.3390/s141224116

Gitelson, A. A., Dall'Olmo, G., Moses, W., Rundquist, D. C., Barrow, T., Fisher, T. R., Holz, J. (2008). A simple semi-analytical model for remote estimation of chlorophyll-a in turbid waters: Validation. Remote Sensing of Environment, 112(9), 3582-3593. https://doi.org/10.1016/j.rse.2008.04.015

Hadjimitsis, D. G., \& Clayton, C. (2009). Assessment of temporal variations of water quality in inland water bodies using atmospheric corrected satellite remotely sensed image data. Environmental Monitoring and Assessment, 159(1-4), 281-292. https://doi.org/10.1007/s10661-008-0629-3

Han, L., \& Jordan, K. J. (2005). Estimating and mapping chlorophyll-a concentration in Pensacola Bay, Florida using Landsat ETM + data. International Journal of Remote Sensing, 26(23), 5245-5254. https://doi.org/10.1080/01431160500219182

Hellweger, F. L., Schlosser, P., Lall, U., \& Weissel, J. K. (2004). Use of satellite imagery for water quality studies in New York Harbor. Estuarine, Coastal and Shelf Science, 61(3), 437-448. https://doi.org/10.1016/j.ecss.2004.06.019

Hoogenboom, H. J., Dekker, A. G., \& Althuis, I. A. (1998). Simulation of AVIRIS sensitivity for detecting chlorophyll over coastal and inland waters. Remote Sensing of Environment, 65(3), 333-340. https://doi.org/10.1016/S0034-4257(98)00042-X

Koponen, S., Pulliainen, J., Kallio, K., \& Hallikainen, M. (2002). Lake water quality classification with airborne hyperspectral spectrometer and simulated MERIS data. Remote Sensing of Environment, 79(1), 51-59. https://doi.org/10.1016/S0034-4257(01)00238-3

Kratzer, S., \& Moore, G. (2018). Inherent optical properties of the Baltic Sea in comparison to other seas and oceans. Remote Sensing, 10(3), 418. https://doi.org/10.3390/rs10030418

Madsen, J. D., Chambers, P. A., James, W. F., Koch, E. W., \& Westlake, D. F. (2001). Modelling Sediment Resuspension, Water Quality and Submersed Aquatic Vegetation. In Hydrobiologia (Vol. 444).

Mannino, A., Russ, M. E., \& Hooker, S. B. (2008). Algorithm development and validation for satellitederived distributions of DOC and CDOM in the U.S. Middle Atlantic Bight. Journal of Geophysical Research: Oceans, 113(7), 1-19. https://doi.org/10.1029/2007JC004493

Morel, A., \& Prieur, L. (1977). Analysis of variations in ocean color. Limnology and Oceanography, 22(4), 709-722. https://doi.org/10.4319/lo.1977.22.4.0709

Myint, S. W., \& Walker, N. D. (2002). Quantification of surface suspended sediments along a river dominated coast with NOAA AVHRR and Sea WiFS measurements: Louisiana, USA. International Journal of Remote Sensing, 23(16), 3229-3249. https://doi.org/10.1080/01431160110104700

Nechad, B., Ruddick, K. G., \& Park, Y. (2010). Calibration and validation of a generic multisensor algorithm for mapping of total suspended matter in turbid waters. Remote Sensing of Environment, 114(4), 854866. https://doi.org/10.1016/j.rse.2009.11.022

Oguz, T., \& Gilbert, D. (2007). Abrupt transitions of the top-down controlled Black Sea pelagic ecosystem during 1960-2000: Evidence for regime-shifts under strong fishery exploitation and nutrient enrichment modulated by climate-induced variations. Deep-Sea Research Part I: Oceanographic Research Papers, 54(2), 220-242. https://doi.org/10.1016/j.dsr.2006.09.010

Pavlic, B., Cepak, F., Sucic, B., Peckaj, M., \& Kandus, B. (2014). Sustainable Port Infrastructure, Practical Implementation of the. Thermal Science, 18(3), 935-948. https://doi.org/10.2289/TSCI1403935P

Petus, C., Waterhouse, J., Lewis, S., Vacher, M., Tracey, D., \& Devlin, M. (2019). A flood of information: Using Sentinel-3 water colour products to assure continuity in the monitoring of water quality trends in the Great Barrier Reef (Australia). Journal of Environmental Management, 248(July), 109255. https://doi.org/10.1016/j.jenvman.2019.07.026

Ritchie, J. C., Zimba, P. V, \& Everitt, J. H. (2003). Remote Sensing Techniques to Assess Water Quality / Técnicas de teledetección para evaluar la calidad del agua. Photogrammetric Engineering \& Remote Sensing, 69(6), 695-704. https://doi.org/10.14358/PERS.69.6.695

Schlichter, D., Kampmann, H., \& Conrady, S. (1997). Trophic potential and photoecology of endolithic algae living within coral skeletons. Marine Ecology, 18(4), 299-317. https://doi.org/10.1111/j.14390485.1997.tb00444.x

Seyhan, E., \& Dekker, A. (1986). Application of remote sensing techniques for water quality monitoring. Hydrobiological Bulletin, 20(1-2), 41-50. https://doi.org/10.1007/BF02291149

Spencer, R. G. M., Ahad, J. M. E., Baker, A., Cowie, G. L., Ganeshram, R., Upstill-Goddard, R. C., \& Uher, G. (2007). The estuarine mixing behaviour of peatland derived dissolved organic carbon and its relationship to chromophoric dissolved organic matter in two North Sea estuaries (U.K.). Estuarine, 
Coastal and Shelf Science, 74(1-2), 131-144. https://doi.org/10.1016/j.ecss.2007.03.032

Stedmon, C. A., Markager, S., Søndergaard, M., Vang, T., Laubel, A., Borch, N. H., \& Windelin, A. (2006). Dissolved Organic Matter (DOM) export to a temperate estuary: Seasonal variations and implications of land use. Estuaries and Coasts, 29(3), 388-400. https://doi.org/10.1007/BF02784988

Toming, K., Kutser, T., Tuvikene, L., Viik, M., \& Nõges, T. (2016). Dissolved organic carbon and its potential predictors in eutrophic lakes. Water Research, 102, 32-40. https://doi.org/10.1016/j.watres.2016.06.012

Usali, N., \& Ismail, M. H. (2010). Use of Remote Sensing and GIS in Monitoring Water Quality. Journal of Sustainable Development, 3(3). https://doi.org/10.5539/jsd.v3n3p228

van der Woerd, H. J., \& Wernand, M. R. (2015). True colour classification of natural waters with mediumspectral resolution satellites: SeaWiFS, MODIS, MERIS and OLCI. Sensors (Switzerland), 15(10), 25663-25680. https://doi.org/10.3390/s151025663

Vignudelli, S., Santinelli, C., Murru, E., Nannicini, L., \& Seritti, A. (2004). Distributions of dissolved organic carbon (DOC) and chromophoric dissolved organic matter (CDOM) in coastal waters of the northern Tyrrhenian Sea (Italy). Estuarine, Coastal and Shelf Science, 60(1), 133-149. https://doi.org/10.1016/j.ecss.2003.11.023

Wang, X., Ling, F., Yao, H., Liu, Y., \& Xu, S. (2019). Unsupervised Sub-pixel water body mapping with sentinel-3 OLCI image. Remote Sensing, 11(3). https://doi.org/10.3390/rs11030327

Wass, P. D., Marks, S. D., Finch, J. W., Leeks, G. J. L., \& Ingram, J. K. (1997). Monitoring and preliminary interpretation of in-river turbidity and remote sensed imagery for suspended sediment transport studies in the Humber catchment. Science of the Total Environment, 194-195(96), 263-283. https://doi.org/10.1016/S0048-9697(96)05370-3

Werdell, P. J., \& Bailey, S. W. (2005). An improved in-situ bio-optical data set for ocean color algorithm development and satellite data product validation. Remote Sensing of Environment, 98(1), 122-140. https://doi.org/10.1016/j.rse.2005.07.001

Yalçın, B., Artüz, M. L., Pavlidou, A., Çubuk, S., \& Dassenakis, M. (2017). Nutrient dynamics and eutrophication in the Sea of Marmara: Data from recent oceanographic research. Science of the Total Environment, 601-602, 405-424. https://doi.org/10.1016/j.scitotenv.2017.05.179

Yu, Q., Tian, Y. Q., Chen, R. F., Liu, A., Gardner, G. B., \& Zhu, W. (2010). Functional linear analysis of in situ hyperspectral data for assessing CDOM in rivers. Photogrammetric Engineering and Remote Sensing, 76(10), 1147-1158. https://doi.org/10.14358/PERS.76.10.1147

Zeri, C., Beşiktepe, Ş., Giannakourou, A., Krasakopoulou, E., Tzortziou, M., Tsoliakos, D., ... Papathanassiou, E. (2014). Chemical properties and fluorescence of DOM in relation to biodegradation in the interconnected Marmara-North Aegean Seas during August 2008. Journal of Marine Systems, 135, 124-136. https://doi.org/10.1016/j.jmarsys.2013.11.019 